\title{
THE URGENCY OF PSYCHIATRIC THERAPY SANCTION IMPOSITION AGAINST PERPETRATORS OF PEDOPHILIA
}

\author{
Y.A. Triana Ohoiwutun \\ Law Faculty of Jember University \\ E-mail: anaohoiwutun@ymail.com
}

\begin{abstract}
The pedophilia crime can be imprisoned under the Criminal Code (KUHP) and the Child Protection Act of 2014 (UU Perlindungan Anak Tahun 2014); whereas pedophile can be qualifild as the psychiatric disorder in accordance with ICD, DSM and PPDGJ definition. The imposition of measures psychotherapy is able to be integrated and synergized with the imprisonment penalty based on the concept of criminal individualization and double track system. Therefore the penalties againts pedophiles could be effective and efficient penalties not only the perpetrators but also for the society.
\end{abstract}

Key words: pedophilia, criminal sanctions, psychiatric therapy.

\begin{abstract}
Abstrak
Tindak pidana pedofilia diancam sanksi pidana penjara di dalam KUHP dan UU Perlindungan Anak Tahun 2014; sedangkan pedofilia dikual-ifikasikan sebagai jenis gangguan jiwa menurut ICD, DSM dan PPDGJ. Pengenaan tindakan terapi kejiwaan dapat diintegrasikan dan disinergikan dengan sanksi pidana penjara berdasarkan konsep indvi-dualisasi pidana dan double track system. Pengenaan sanksi pidana terhadap pelaku pedofilia merupakan sarana yang efektif dan efisien, baik bagi individu pelaku maupun masyarakat.
\end{abstract}

Kata kunci: pedofilia, sanksi pidana, terapi kejiwaan.

\section{Introduction}

Crimes against children in the form of sexual violence in Indonesia lately coveraged by mass media. The case of pedophilia happened in Sukabumi with dozens of children, then Jakarta International School (JIS) case, some cases then happened in Bandung, Kelapa Gading Jakarta, Pontianak, and the latest case is the murder of 9-year daughter which her corpse were found in cardboard boxes in Jakarta. The increasement of paedophilia cases indicates a sexual violence threat to Indonesian children by adults.

Pedophilia is a clinical diagnosis, made by a psychiatrist or psychologist, that is over a period of at least six months, a strong sexual drive to or sexually aroused by a child 13 years old or younger; people with pedophilia, at least 16 years old and at least five years younger than his victim. ${ }^{1}$ Pedophilia in the context of criminal law was declared a criminal act with the threat of criminal sanctions of imprisonment according to the KUHP and Act No. 35 year 2014 in changes to the Act No. 23 of 2002 about child protection (here in after referred to the child protection ACT year 2014).

The verdict of imprisonment against perpretators of pedophiles in some cases indeed is the implementation of laws provisions that have been violated, however, is the imposition of criminal sanctions in prison enough? Infact, cases of pedophilia have swallowed many children victims of Indonesia which is the real threat to the younger generation of the successor Nations. The threat term, is inseparable with the impact term, as both are always hand in hand, if there is a threat and aren't addressed properly, surely 
there will be an impact. ${ }^{2}$ Cases of pedophilia that have swallowed the children of Indonesia as a victim, if not addressed and handled correctly, it will have an impact on the future of the younger generation life. Result of T. Karen research ${ }^{3}$ indicates that the public considers sexual crimes as crimes that are dangerous, because rape is consi-dered potentially experiencing repetition and the community considers, that the offender undergoes psychiatric.

Pedophilia is abnormal behaviour and classified as soul disorders, so beside imposi-tion of criminal sanction in prison also required psychiatric therapy. The imposition of sanctions which are prospective and oriented to the future is part of the purpose of criminal paradigm change. According to Frans Maramis, flow of criminology requires existence of individualization, so that each of the villains correspond with the healing way of gaining. ${ }^{4}$ Among the sanctions criminal with the perpetrators of the criminal act must be suitability, so that the purpose for which such criminal sanctions can be reached, then the judge in meting out criminal sanctions should pay attention to the nature or character of the perpetrators of criminal acts. ${ }^{5}$ Different from the concept of individualization that prioritizes criminal personality, traits and character of the offender, therefore it required congruency and precision of the sanctions imposition against pedophilia perpetrators whose have interrupted psychiatric condition.

Criminal liability only happens when people do criminal acts. In a broader sense include three principal issues of liability in criminal law. A very basic thing are 3 (three) staple issues in criminal law according to Sauer, that is against

2 Soepono Soegirman, "Net Konsep Runtuhnya Singasari Dalam Perspektif Ancaman”, Cendekia Waskita: Jurnal Kajian Strategis, Vol. 1 No.2 November 2014, Bogor: Sekolah Tinggi Intelijen Negara, page 88.

3 Fathul Lubabin Nuqul, "Peran Usia Pelaku Dalam Sikap Masyarakat Awam Terhadap Pelaku Kejahatan Seksual Pada Anak", Psikologika: Jurnal Pemikiran dan Penelitian Psikologi, Vol. 18 No. 2 July 2013, Yogyakarta: Psichology Study Program of Psichology and Humanities Faculty Universitas Islam Indonesia, page 108.

4 E.Z. Leasa, "Penerapan Sanksi Pidana dan Sanksi Tindakan (Double Track System) dalam Kebijakan Legislasi", Jurnal Sasi, Vol. 16 No. 4 October - December 2010, Ambon: Universitas Patimura, page 55. the law of nature (unrecht), error (schuld), and criminal (straf). ${ }^{6}$ The overthrow of criminal sanctions of im-prisonment in some cases of pedophilia error indicates a perpetrator and indeed actions are against the law. The determination of criminal liability based on fault maker (liability based on fault), and not just on satisfy the elements of a criminal offence, the subjective element is the fault of self abusers. Basic geen straf zonder schuld as the principle culpability states expressly exclude the criminal if without error, and the imposition of criminal sanctions against perpetrators of pedophile prison is a form of censure for the error of the perpetrator.

Author is focused on the study of psychiatric therapy Act of imposition of urgency against the offender pedophiles that need to be integrated and the synergy with the imposition of criminal sanctions. The main focus in this issue is, how does the urgency of sanctions against psychological therapy of pedophilia perpetrators?

\section{Discussion}

Indonesia's legal system, both in the field of criminal law, civil law, and the law of the State is still using the legal system and the method of approach to the legal system of Civil Law, which puts the codification of the law as a law source only in the practice of application of law. ${ }^{7}$ The consequences of the Civil Law legal system adhered, codification of written legislation or regulations are a source of primary law used by the judge in the case shall be disconnected, and the consequences of the imposition of imprisonment logically against perpetrators of pedophilia is clearly not in conflict with the law.

5 Dey Ravena, “Implementasi Kebijakan Berwawasan Restorative Justice Pembinaan Narapidana dalam Sistem Peradilan Pidana di Indonesia", Jurnal Ilmu Hukum Litigasi, Vol. 10 No. 1 February 2009, Bandung: Fakultas Hukum Universitas Pasundan, page 2-3.

6 Yeni Widowaty, "Pertanggungjawaban Pidana Korporasi Terhadap Korban Dalam Kasus Tindak Pidana Lingkungan Hidup Kajian Putusan MA Nomor 862K/Pid.Sus/2010", Jurnal Yudisial, Vol. 5 No. 2 August 2012, Jakarta: Komisi Yudisial, page 160.

7 Romli Atmasasmita, "Tiga Paradigma Hukum dalam Pembangunan Nasional”, Jurnal Hukum Prioris, Vol. 3 No. 1 Year 2012, Jakarta: Universitas Trisakti, page 3. 
According Marcus Priyo Gunarto a criminal, ${ }^{8}$ is a special type of people that has organic and mental disorders, so it is not a crime that should be imposed on them, but it is a necessary treatment measures that aim fix. Different from the opinion of Gunarto, a mental abnormality or a pedophile offender soul have perverted sexual orientation, obviously need mental health care action given by experts of the soul, and can't be cured only with the imposition of criminal sanctions of imprisonment.

Related to deviant sexual behavior as the personal circumstances of the perpetrator of the crime of pedophilia is a characteristic and mental condition are specialized, with different perpetrators of criminal acts in General. Therefore, the need to apply the concepts of the individualization of criminal containing particular characteristics. According to Barda Nawawi Arief individualization of criminal characteristics includes first, the Criminal Case is personal; second, the Criminal must be given to those who trespass (basic culpabilitas); third, the Criminal must be tailored to the characteristics and conditions of the offender. ${ }^{9}$

Modern criminal law among others characterized by, prefer the human person as the perpetrator of the criminal offence than the Criminal deeds that have been done, so that the imposition of sanctions is not intended for retaliation, but more prospective in nature and oriented to the future. The imposition of sanctions in order to achieve the ideal destination, according to the perpetrator of the crime personally, then there should be a conditio sine qua non of the relationship regarding the alignment of the imposition of sanctions with personal character individualization concepts as criminal offender. The judge's task to assess and then dropped the criminal sanctions and sanctions or action.

8 Marcus Priyo Gunarto, "Sikap Memidana yang Berorientasi Pada Tujuan Pemidanaan", Jurnal Mimbar Hukum, Vol. 21 No. 1 February 2009, Yogyakarta: Universitas Gajah Mada, page 97.

9 Ibid, page 105

10 Ifrani, "Kajian Filsafat Hukum Tentang Kedudukan Hukum Dalam Negara Ditinjau Dari Perspektif Keadilan", Jurnal Konstitusi, Vol. 1 No. 1 November 2012, PKK Fakultas Hukum Universitas Bengkulu in cooperation with Mahkamah Konstitusi Republik Indonesia, page 79.
The applicability or enforcement, often the task of the judge not merely apply the law, ${ }^{10}$ and in practice law enforcement for law enforcement agencies, legislation is interpretative concept, there is room for law enforcement officers to investigators, prosecutors, police, investigators of $\mathrm{KPK}$, and the judges to perform in the framework of interpretation of the selection, placement, and application of law. ${ }^{11}$ The judge's task is not just to apply legislation but the existence of the interpretative concept in the examination of criminal cases, represents the powers of judges are absolute. The absolute authority of judges in criminal cases is limited by break the Criminal Procedure (KUHAP) of article 183 and 184, however, absolute power the judge gives the opportunity to the fullest for it did discretion which is subjective in law enforcement. According Wayne La Favre. ${ }^{12}$ There are some things about the discretion in law enforcement is very important. First, there is no such legislation. Second, the existence of slownesslags for adjustment of legislation with developments in society, giving rise to the lack of uncertainty. Third, the lack of cost to implement legislation as desired by the founding act. Fourth, the existence of the individual cases that need handling in particular.

Different from opinion of La Favre, especially the second and the fourth thing, where there was slowness for adjustment of legislation with the developments in the society, in this case the development of the science of psychiatry and psychology related to the concept of psychiatric diagnosis. The existence of the individual cases that require special handling, such as the case of pedophilia, then the task of the judge who not only apply the law but the existence of authority using interpretative concept through the subjective discretion, the judge in

11 Aulia A. Rachman, "Strategi Penegakan Hukum Mengatasi Mafia dan Korupsi”, Jurnal Intelijen dan Kontra Intelijen, Vol. VI No. 35 August 2011, Jakarta: Center for the Study of Intelligence and Counter Intelligence (CSICl), page 49.

12 Yusriadi, "Polisi dan Aspek Penegak Hukum Secara Sosiologis”, Jurnal Hukum Progresif, Vol. 4 No. 1 April 2008, Semarang: Program Doktor Ilmu Hukum Universitas Diponegoro, page 82. 
examining and disconnect power to decide criminal cases based on double track system, namely the imposition of imprisonment were integrated and synergy with actions of psychiatric therapy against perpetrators of pedophile.

Condemnation spent relative much, the cost of the process in the courts, jail, parole, consultation centers that must be attended, and collection of fines. ${ }^{13}$ The crime of pedophilia that threatens criminal sanctions of imprisonment specified in KUHP article 287, article 292, and article 294; The Child Protection Act Year 2014 Article 81 and Article 82 in the implementation, clear social cost is high, in addition to other excesses. The existence of a high social cost, would of course have to consider also the advantages that can be obtained. The handling of pedophilia cases that requires high social costs in legal proceedings should be accompanied with the principle of prudence, considering cost and benefit, also efficient and effective. The principle of prudence, consider the cost and the benefit, in dealing with cases of pedophilia would be effective and efficient, in the imposition of criminal sanctions of imprisonment as specified in the KUHP and The Child Protection Act Year 2014 accompanied with actions of psychiatric therapy.

The crime of pedophilia have special characteristics with regard to the condition of the soul of the offender behave sexually deviant. Pedophile sexual behavior is included in the disturbances of the soul as specified in the International Classification of Diseases-10 (commonly abbreviated to ICD), published by the WHO (World Health Organization) and the Diagnostic and Statistical Manual of Mental Disorder-IV (commonly abbreviated to DSM) published by the American Psychiatric Association (commonly abbreviated APA). DSM-IV Text Revision Classification, classifies paedophilia to the paraphilias with the code 302.2; While the ICD-10 classifies

13 Syaiful Bakhri, "Pengaruh Aliran-aliran Falsafat Pemidanaan dalam Pembentukan Hukum Pidana Nasional", Jurnal Hukum lus Quia lustum No. 1 Vol. 18 Januari 2010, Yogyakarta: Universitas Islam Indonesia, page 137.

14 Harold I. Kaplan, Benjamin J. Sadock, Jack A, op.cit, page 481 . paedophilia with the code F 40.6. Standard system ICD and DSM has changed the code on the last revision so that the guidelines can be compared, although there are still significant differences, that all thecategories used in the DSM IV found in the ICD-10 but not all ICD-10 category exists in DSM-IV. ${ }^{14}$ Indonesia in determining classification Guidelines specified in the Psychiatric Diagnosis of Psychiatric Classification (commonly abbreviated as PPDGJ) by using the standard DSM.

PPDGJ III classifies paedophilia with the code $F \quad 40.6$ is a sexual preference disorders is disturbance of personality and behavior of adulthood. ${ }^{15}$ Diagnostic guidelines on pedophilia in the PPDGJ III refers to the DSM-IV specifies: sexual preference against children, usually prepuberty or early prepuberty, both menand women; pedophiles rarely found on women; preferences should be repeated and settled; including adult male who had a sexual partner preferences of adult, but because the experience of chronic frustration that to achieve the expected sexual relationship, then it is customary to include the children instead of. ${ }^{16}$

Refer to the ICD 10 and DSM IV, and PPDGJ III, pedophilia is a distraction and an aberrant sexual behavior, making sanctions imposition of imprisonment without accompanied by a psychiatric therapy will not change the desire or sexual fantasies convict as the sufferer; the handling of pedophilia via proper psychiatric therapy can be cured by action psychotherapy and pharmacotherapy aimed at changing the sexual drive. Psychotherapy oriented to the divination that is an approach that is often done, allowing patients regain self-esteem and improve interpersonal skills and find an acceptable method to get sexual satisfaction; ${ }^{17}$ and pharmacotherapy done through drug therapy and other organic therapy. ${ }^{18}$ Therapeutic approach in psychitrictherapy, through a combination of psychothera-

15 Rusdi Maslim (Ed.), 2008, Buku Saku Diagnosis Gangguan Jiwa, Rujukan Ringkas dari PPDGJ-III, Jakarta: Bagian Ilmu Kedokteran Jiwa FK-Unika Atmajaya, page 110.

16 Ibid, page 113.

17 Harold I. Kaplan, Benjamin J. Sadock, Jack A. Grebb, op.cit, page 179 .

18 Ibid, page 459. 
py and pharmacotherapy or "pharmacotherapy oriented psychotherapy" this is more superior and effective. ${ }^{19}$ The concept of a double track system can be applied for the purpose of the effectiveness and the efficiency of sanctions against perpetrators of pedophile. The imposition of the sanctions Act of psychiatric therapy "pharmacotherapyoriente-psychotherapy" which are integrated and synergy with criminal sanctions of imprisonment is an implementation of the concept of a double track system in dealing with the perpetrators of the crime of pedophilia.

The imposition of psychiatric therapy action that are integrated and synergy with criminal sanctions of imprisonment, using descriptive normative system. Against the person who allegedly interrupted their soul in the examination conduct, the judge may request an expert opinion for the soul purposes of propriety, success and their effectiveness. Related to offender pedophiles and imposition of psychiatric therapy action perspective, is required expert examination of the soul in the diagnosis to determine the presence of soul disorders and the psychiatric therapy prognosis to determine the actions that will be imposed against the perpetrators. In the prognosis, the examination of forensic psychiatry and forensic psychology relating to an opinion about a possible trip immediately and in the future, the level and the consequent disruption of the soul of pedophilia.

Psychology in law, is the practical application of the psychology in the areas of law such as the psychologist were invited to be an expert witness in the justice process. ${ }^{20}$ The implementation of the checks with prognosis in the examination of forensic psychiatry and forensic psychology in its function as psychology in law can be helpful in determining the type of time, place, and by whom the action of psychiatric therapy can be given against perpetrators of pedophile. Role of the expert examination in the diagnosis of the soul in useful as scientific inves-

19 Ibid, page 466.

20 Yusti Probowati R, “Peran Psikologi Forensik dalam Proses Hukum di Indonesia", Indonesian Journal of Legal and Forensic Sciences (IJLFS), Vol. 1 No. 1 January 2008, Jakarta: Departemen Ilmu Kedokteran Forensik dan Me- tigation, thai is to determine or no disruption of the soul the pedophilia as specified in the ICD, DSM and PPDGJ, and the prognosis to determine the type of psychiatrictherapy action that will be integrated and synergy with criminal sanctions of imprisonment.

Psychiatric therapy against perpetrators of pedophile may be made on the recommendation of the experts stated in the ruling of the judges. Further integration of the synergy between the implementation of criminal sanctions a prison with psychiatric therapy in action, expected to reach the goal of condemnation containing two principal aspects. ${ }^{21}$ First, aspect of the society protection against crime. Second, individual coaching/protection aspects of the criminal offence perpetrator (criminal aspects of individualization). Overthrow of criminal sanctions against pedophile perpetrators prison can provide protection of society, particularly children from deed distorted sexual behavior; while aspects of protection/construction of psychiatric therapy, the perpetrator actions is expected to provide iniquity of its perpetrator education and awareness.

Imposition of psychiatric therapy is widely done for the purpose of obtaining mental health services that are curative and rehabilitative. Based on the Act No. 18 year 2001 about mental health Article 18, curative efforts for healing or recovery, reduction of suffering, disability and control symptoms of the disease; while rehabilitative efforts aimed at preventing or controlling the disability, restoring social functions, recover and prepare occupational functions and gives the ability of self-reliance in the society of people with soul disorders. The imposition of criminal sanctions are accompanied by psychiatric therapy against pedophilia perpetrators; thus can meet the elements of humanitarian, educational and justice, which synergize with the concept of a healthy paradigm as specified in the Act No. 36/2009 about health, that includes the

dikolegal Fakutas Kedokteran Universitas Indonesia, page 28.

21 Barda Nawawi Arief, 2009, Tujuan dan Pedoman Pemidanaan Perspektif Pembaharuan Hukum Pidana dan Perbandingan Beberapa Negara, Semarang: Badan Penerbit Universitas Diponegoro, page 49. 
healthy physical, mental, social, spiritual or allow everyone to live a productive, socially and economically .

The imposition of psychiatric therapy action against pedophilia perpetrators is the application development of science in the field of Psychiatry and psychology, so rationally can be accounted for scientific truth. Rationality is the hallmark of science is scientific, and in fact there is an intersection between law science with the science of Psychiatry and psychology, that is aimed at goodness and decency to behave in the achievement of security, peace and peace of life of each person in the society. Assistance in legal psychology has a different focus. However it is associated with the criminal justice system is an open system (open systems), has some experience in interaction, interconnection and interdependence, so that the development of science outside of the criminal law, be able to support the works of the criminal justice system. The development of science and technology as one of the sub systems contribute to works of the criminal justice system.

\section{Closing}

\section{Conclusion}

Conclusions that can be drawn with regard to the urgency of the imposition of psychiatric therapy in action against the perpetrators of the pedophilia crime according to the ICD 10 and DSM IV, and PPDGJ III, pedophilia is a sexual deviant behavior that is classified as disorders of the soul. The use of individualization concepts of criminal and double track system means psychiatric therapy, the action can be integrated and synergy with the imposition of imprisonment criminal sanctions.

\section{Suggestion}

Pedophilia is classified as disorders of the soul, so that the imposition of criminal sanctions of imprisonment needs to be accompanied with psychiatric therapy. The urgency of action integrated psychiatric therapy and synergy with criminal sanctions against perpetrators of prison pedophile can bolster the effectiveness and efficiency of the works of the sanctions. Sugges- tion that can be given as the end of this writing that is supposed to be the judge in a lawsuit in the case of termination of pedophilia are prospective and oriented to the future, that is for the benefit of the offender and also (prospective) victim.

\section{Bibliography}

Atmasasmita, Romli. "Tiga Paradigma Hukum dalam Pembangunan Nasional". Jurnal Hukum Prioris, Vol. 3 No. 1 Year 2012. Jakarta: Trisakti University;

Bakhri, Syaiful. "Pengaruh Aliran-aliran Falsafat Pemidanaan Dalam Pembentukan Hukum Pidana Nasional". Jurnal Hukum Ius Quia lustum. No. 1 Vol. 18 January 2010. Yogyakarta: Universitas Islam Indonesia;

Gunarto, Marcus Priyo. "Sikap Memidana yang Berorientasi Pada Tujuan Pemidanaan". Jurnal Mimbar Hukum. Vol. 21 No. 1 February 2009. Yogyakarta; Gajah Mada University: Law Faculty;

Ifrani. "Kajian Filsafat Hukum Tentang Kedudukan Hukum Dalam Negara Ditinjau Dari Perspektif Keadilan". Jurnal Konstitusi, Vol. 1 No. 1 November 2012. Bengkulu: PKK Law Faculty, Bengkulu University in Cooperation with Mahkamah Konstitusi Republik Indonesia;

Kaplan, Harold I., Benjamin J. Sadock, Jack A. Grebb, (Interpreter Widjaja Kusuma). 2010. Kaplan and Sadock Sinopsis Psikiatri Ilmu Pengetahuan Perilaku Psikiatri Klinis Vol. 2. Tangerang: Binarupa Aksara;

Leasa, E.Z. "Penerapan Sanksi Pidana Dan Sanksi Tindakan (Double Track System) Dalam Kebijakan Legislasi”. Jurnal Sasi Vol. 16 No. 4 October - December 2010. Ambon: Patimura University;

Maslim, Rusdi (Ed.). 2008. Buku Saku Diagnosis Gangguan Jiwa, Rujukan Ringkas dari PP. DGJ-III. Jakarta: Bagian Ilmu Kedokteran Jiwa FK-Unika Atmajaya;

Meliala, Adrianus. Kontribusi Psikologi dalam Dunia Peradilan: Dimana dan Mau Kemana, Indonesian Journal of Legal and Forensic Sciences (IJLFS) Vol. 1 No. 1 January 2008;

Nawawi Arief, Barda. 2009. Tujuan dan Pedoman Pemidanaan Perspektif Pembaharuan Hukum Pidana dan Perbandingan Bebe- 
rapa Negara. Semarang: Badan Penerbit Universitas Diponegoro;

Nuqul, Fathul Lubabin. "Peran Usia Pelaku dalam Sikap Masyarakat Awam Terhadap Pelaku Kejahatan Seksual Pada Anak". Psikologika: Jurnal Pemikiran and Penelitian Psikologi, Vol. 18 No. 2 July 2013 edition. Yogyakarta: Program Studi Psikologi Fakultas Psikologi dan Ilmu Sosial Budaya Universitas Islam Indonesia;

Probowati R, Yusti. "Peran Psikologi Forensik dalam Proses Hukum di Indonesia". Indonesian Journal of Legal and Forensic Sciences (IJLFS) Vol. 1 No. 1 January 2008;

Rachman, Aulia A. "Strategi Penegakan Hukum Mengatasi Mafia dan Korupsi". Jurnal Intelijen dan Kontra Intelijen. Vol. VI No. 35 August 2011. Jakarta: Center for the Study of Intelligence and Counter Intelligence $(\mathrm{CSICl})$;
Ravena, Dey. "Implementasi Kebijakan Berwawasan Restorative Justice Pembinaan Narapidana dalam Sistem Peradilan Pidana di Indonesia". Jurnal Ilmu Hukum Litigasi. Vol 10 No 1 February 2009 Edition. Bandung: Law Faculty Universitas Pasundan;

Soegirman, Soepono. "Net Konsep Runtuhnya Singasari dalam Perspektif Ancaman". Cendekia Waskita: Jurnal Kajian Strategis. Vol. 1 No.2 November 2014. Bogor: Sekolah Tinggi Intelijen Negara;

Widowaty, Yeni. "Pertanggungjawaban Pidana Korporasi Terhadap Korban dalam Kasus Tindak Pidana Lingkungan Hidup Kajian Putusan MA Nomor 862K/Pid.Sus/2010". Journal of Yudisial. Vol. 5 No. 2 August 2012. Jakarta: Komisi Yudisial;

Yusriadi. "Polisi dan Aspek Penegak Hukum Secara Sosiologis". Jurnal Hukum Progresif. Vol. 4 No. 1 April 2008. Semarang: Program Doktor Ilmu Hukum Universitas Diponegoro. 